\title{
Age and growth, reproduction and diet of a sublittoral population of the rock goby Gobius paganellus (Teleostei, Gobiidae)
}

\author{
José Manuel N. Azevedo \& Ana Maria V. Simas \\ Departamento de Biologia, Universidade dos Açores, Rua Mãe de Deus, 9500 Ponta Delgada, Portugal \\ Tel. 351296 653044.E-mail: azevedo@notes.uac.pt
}

Key words: fish biology, length-weight relationship, length-frequency distributions, modal analysis, growth rate, life span

\begin{abstract}
Basic biological information for a sublittoral population of the rock goby Gobius paganellus Linnaeus, 1758 is presented based on a 2-year study involving 1680 specimens. The length-weight relationship was given by TW $=0.0089 * \mathrm{TL}^{3.163}$ (where $\mathrm{TW}=$ total weight in $\mathrm{g} ; \mathrm{TL}=$ total length in $\mathrm{mm}$ ). Age at length data were inferred by modal analysis of the monthly length-frequency distributions. The parameters of the fitted Von Bertalanffy growth equation (with seasonal component, birth date on the 1 st of January) were $L_{\infty}=13.8 \mathrm{~cm} ; K=0.73 \mathrm{yr}^{-1} ; t_{\mathrm{o}}=$ $-0.22 \mathrm{yr} ; C=0.95 ; W=0.07$. This growth rate is much higher than that described for northern Europe populations (where $K$ is about $0.3 \mathrm{yr}^{-1}$ ) and is probably associated with a shorter life span. Macroscopic examination of the gonads, and analysis of the monthly values of the gonadosomatic index, indicated that reproduction occurs in winter and early spring, with a maximum in February and March, when water temperatures are lowest. Individuals become sexually mature around 6-7 cm TL, a size that can be reached in less than 1 year. By contrast, individuals of this goby in the British Isles mature in their second or third year. Stomach contents were mainly small benthic invertebrates, predominantly crustaceans.
\end{abstract}

\section{Introduction}

The rock goby Gobius paganellus Linnaeus, 1758 is a relatively large goby found along the northwest Atlantic coastline, from western Scotland to Senegal, and on the Atlantic islands of the Azores, Madeira and the Canaries (Miller, 1986). It is the only species of Gobius from the Azores (Miller, 1984) and is considered mainly as an intertidal species (Miller, 1986). The two major studies of its biology (Miller, 1961; Dunne, 1978) used intertidal animals as a matter of convenience, however, Dunne (1978) recognized that the species is common subtidally "to a depth of approximately five metres". In the Azores, G. paganellus is found in the rocky subtidal down to $15 \mathrm{~m}$ (Patzner et al., 1992), where it is one of the most abundant benthic species, together with Tripterygion delaisi, Parablennius incognitus and $P$. ruber (Azevedo, 2000). This paper describes various aspects of the biology of a sublittoral population of G. paganellus at São Miguel (Azores).

\section{Materials and methods}

Between December 1993 and November 1995, 1680 specimens were captured at 3-5 m depth on a rocky reef near Ponta Delgada harbour. One to three samples were taken each month by SCUBA diving, using rotenone (3-67 animals per month, average 23, standard deviation 18). Each specimen was measured (total length, TL, to the nearest $\mathrm{mm}$ below), weighed (total wet weight, TW, in $\mathrm{g}$ ), fixed in formalin and transferred to $70 \%$ ethanol after 2-4 weeks. Later, a monthly sub-sample of up to five specimens for each 1 $\mathrm{cm}$ length class was selected. Each of these was sexed by external examination of the shape of the genital papilla (following Miller, 1961) and by macroscopic observation of the gonads, which were removed and weighed (gonad weight, GW, in g). Gonad observation and weighing was not generally possible for smaller specimens $(<5 \mathrm{~cm}$ TL). A gonosomatic index (GSI) was calculated as GSI=GW/(TW-GW)*100. Stomach contents, from 2 to 6 specimens in each monthly 
Table 1. Length-frequency distribution of male and female Gobius paganellus. Asteriscs indicate the probability of the deviations from a 1:1 sex ratio, calculated from the binomial distribution $\left(* p<0.05 ;{ }^{* * *} p<0.001\right)$

\begin{tabular}{rrc}
\hline TL $(\mathrm{cm})$ & Females & Males \\
\hline 2 & 8 & 1 \\
3 & 19 & 3 \\
4 & 42 & $10^{*}$ \\
5 & 20 & 49 \\
6 & 143 & 65 \\
7 & 134 & $99^{* * *}$ \\
8 & 165 & 121 \\
9 & 99 & $147 *$ \\
10 & 26 & $96^{* * *}$ \\
11 & 1 & $13^{* * *}$ \\
12 & 1 & 4 \\
13 & & \\
& & 726 \\
$N$ & 690 & 8.5 \\
Average & 1.7 & $p<0.001$ \\
\hline St. deviation & 5.058 &
\end{tabular}

sample selected to cover the entire size range present, were removed and placed in $70 \%$ ethanol. They were sorted under a dissecting microscope and identified to the lowest possible taxonomic rank. Results are presented as percentage occurrence in the stomachs (i.e. number of stomachs with item over total number of stomach contents examined).

Age at length data were deduced from modal analysis of the monthly length-frequency distributions and used to calculate the parameters of the Von Bertalanffy seasonalized growth equation, following the methods described in Sparre \& Venema (1992) and using the FiSAT software (Gayanillo et al., 1994). The 1 st of January was chosen as the date of birth. Agelength data for this species were read from graphs in Miller (1961) and Dunne (1978), and converted to total length. The age-length points obtained for these populations were used to determine their Von Bertalanffy parameters in the same way as data from the present study.

\section{Results}

Age and growth

Table 1 shows the length-frequency distributions of sexed individuals. There is a statistically significant

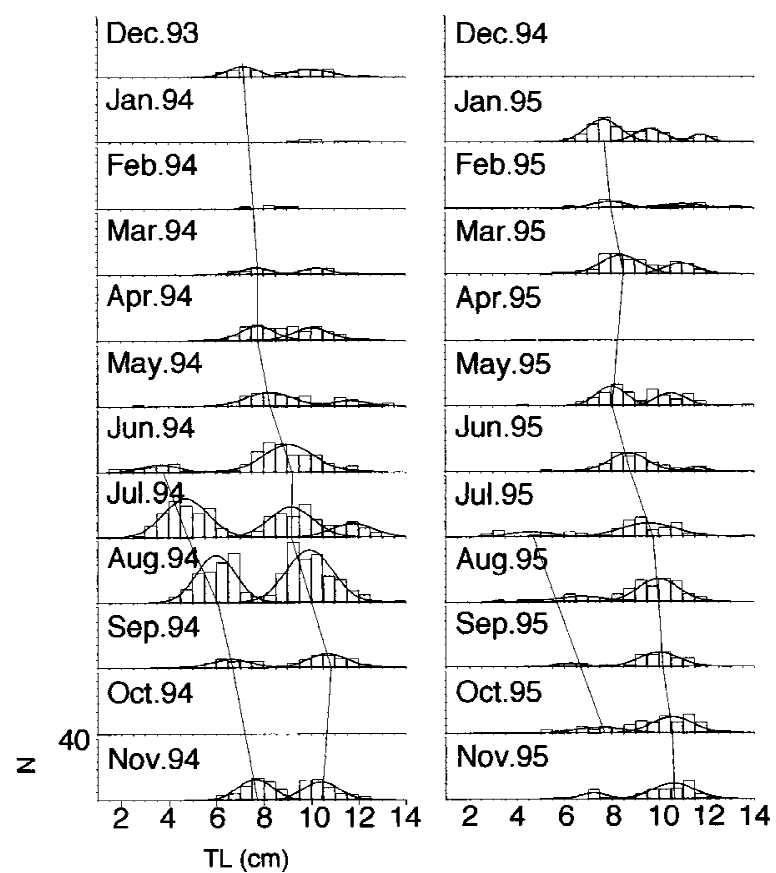

Figure 1. Monthly length-frequency distributions of Gobius paganellus, with superimposed normal curves from modal analysis.

difference in average total length between males and females due, mainly, to the higher proportion of males in the largest length classes. The length-weight relationship, calculated separately for each sex, was found to be statistically identical. The relationship for the entire sample is:

$$
\mathrm{TW}=0.0089 * \mathrm{TL}^{3,163} \quad(n=1152 ; r=0.995) .
$$

The monthly length-frequency distributions, and respective modal analysis, are given in Figure 1, both sexes were considered together. Several well-defined modes can be seen and a displacement to the right can be followed between successive months. These modes were assumed to correspond to distinct age groups, or cohorts. The 1994 cohort was the most distinct and can be traced from its beginning in June 1994 up to the end of the sampling period. The 1993 cohort was deduced by comparison and its displacement could be followed until November 1994. Small specimens were also captured in the summer of 1995 but in much smaller numbers than the previous year, making it difficult to follow its modal progression. Based on these premises, an age-length key was computed (Table 2). This key contains enough age-length points to allow the adjustment of a von Bertalanffy growth curve with 
Table 2. Age-length key for the Azorean population of Gobius paganellus, based on modal analysis data

\begin{tabular}{|c|c|c|c|c|c|c|c|c|c|c|c|c|}
\hline \multirow[t]{3}{*}{ Date } & \multicolumn{4}{|c|}{1993} & \multicolumn{4}{|c|}{1994} & \multicolumn{3}{|c|}{1995} & \multirow[b]{3}{*}{$n$} \\
\hline & \multirow{2}{*}{$\begin{array}{c}\text { Age } \\
\text { (years) }\end{array}$} & \multicolumn{2}{|c|}{ TL (cm) } & \multirow[b]{2}{*}{$n$} & \multirow{2}{*}{$\begin{array}{c}\text { Age } \\
\text { (years) }\end{array}$} & \multicolumn{2}{|c|}{ TL (cm) } & \multirow[b]{2}{*}{$n$} & \multirow{2}{*}{$\begin{array}{c}\text { Age } \\
\text { (years) }\end{array}$} & \multicolumn{2}{|c|}{ TL (cm) } & \\
\hline & & Average & St.dv. & & & Average & St.dv. & & & Average & St.dv. & \\
\hline $9 / 12 / 93$ & 0.94 & 7.1 & 0.5 & 18 & & & & & & & & \\
\hline $10 / 3 / 94$ & 1.19 & 7.7 & 0.6 & 12 & & & & & & & & \\
\hline $12 / 4 / 94$ & 1.28 & 7.8 & 0.8 & 39 & & & & & & & & \\
\hline $11 / 5 / 94$ & 1.36 & 8.3 & 1 & 50 & & & & & & & & \\
\hline $8 / 6 / 94$ & 1.43 & 9 & 1.2 & 103 & 0.43 & 3.4 & 0.9 & 21 & & & & \\
\hline $19 / 7 / 94$ & 1.55 & 9.3 & 0.9 & 86 & 0.55 & 4.7 & 0.9 & 112 & & & & \\
\hline $18 / 8 / 94$ & 1.63 & 10 & 1 & 171 & 0.63 & 6 & 0.8 & 118 & & & & \\
\hline $24 / 9 / 94$ & 1.73 & 10.7 & 0.9 & 40 & 0.73 & 6.7 & 0.8 & 22 & & & & \\
\hline $9 / 11 / 94$ & 1.85 & 10.4 & 0.8 & 46 & 0.85 & 7.7 & 0.7 & 48 & & & & \\
\hline $18 / 1 / 95$ & & & & & 1.05 & 7.7 & 0.6 & 50 & & & & \\
\hline $18 / 2 / 95$ & & & & & 1.13 & 7.8 & 0.6 & 11 & & & & \\
\hline $13 / 3 / 95$ & & & & & 1.19 & 8.4 & 1 & 59 & & & & \\
\hline $5 / 5 / 95$ & & & & & 1.51 & 8 & 0.7 & 40 & & & & \\
\hline $5 / 6 / 95$ & & & & & 1.42 & 8.8 & 0.9 & 55 & & & & \\
\hline $10 / 7 / 95$ & & & & & 1.52 & 9.6 & 1.2 & 55 & 0.52 & 4.6 & 1.5 & 14 \\
\hline $16 / 8 / 95$ & & & & & 1.62 & 10 & 0.9 & 68 & & & & \\
\hline $26 / 9 / 95$ & & & & & 1.73 & 10.1 & 0.8 & 41 & & & & \\
\hline $26 / 10 / 95$ & & & & & 1.82 & 10.6 & 1 & 51 & 0.82 & 7.7 & 1.4 & 26 \\
\hline $18 / 1 / 95$ & & & & & 1.88 & 10.6 & 0.8 & 39 & & & & \\
\hline
\end{tabular}

a seasonal component. The parameters obtained were:

$$
\begin{array}{r}
L_{\infty}=12.77 \mathrm{~cm} ; K=0.89 \mathrm{yr}^{-1} ; \\
t_{\mathrm{O}}=-0.16 \mathrm{yr} ; C=0.99 ; W=0.06
\end{array}
$$

The $L_{\infty}$ obtained is smaller than the length of the largest specimen captured $(13.8 \mathrm{~cm})$. The latter is also the value obtained by the Powell-Wetherall method (see Sparre \& Venema, 1992). When this value of $\mathrm{L} \infty$ is made invariable, the new equation parameters become:

$$
\begin{array}{r}
L_{\infty}=13.8 \mathrm{~cm} ; K=0.73 \mathrm{yr}^{-1} ; \\
t_{\mathrm{o}}=-0.22 \mathrm{yr} ; C=0.95 ; W=0.07
\end{array}
$$

This growth curve, and the points used for its computation, are show in Figure 2. This figure also shows the growth curves calculated from the data of Miller (1961) and Dunne (1978), whose parameters are, respectively:

$$
\begin{array}{r}
L_{\infty}=12.00 \mathrm{~cm} ; K=0.31 \mathrm{yr}^{-1} ; \\
t_{\mathrm{o}}=-0.32 \mathrm{yr} ; C=1 ; W=1 \\
L_{\infty}=14.15 \mathrm{~cm} ; K=0.27 \mathrm{yr}^{-1} ; \\
t_{\mathrm{o}}=-0.03 \mathrm{yr} ; C=0.86 ; W=0.85
\end{array}
$$

The Azores population has a much higher growth rate, measured by $K$. In their first year, Azorean rock gobies attain an average size double that of their northern conspecifics. Values within $10 \%$ of $L_{\infty}$ are attained in just 3 years in the Azores, compared with 7-8 years in the British Isles populations.

\section{Reproduction}

Monthly changes in gonadosomatic index for each sex are shown in Figure 3. Minimum values were observed between July and November, and maximum values between January and May. Females with ripe gonads (oocytes extruding under light pressure on the abdomen) were observed mainly in February and March, suggesting that reproduction occurs in winter and early spring.

The relationship between length and the gonadosomatic index is given in Figure 4. Well developed gonads were found only in specimens with total length equal to or greater than $6 \mathrm{~cm}$ (males) or $7 \mathrm{~cm}$ (females). These, presumably, represent the size at first sexual maturation for this population. According to the growth equation calculated above, males and females can reach sexual maturity in the reproductive season immediately following the one in each they were born. 


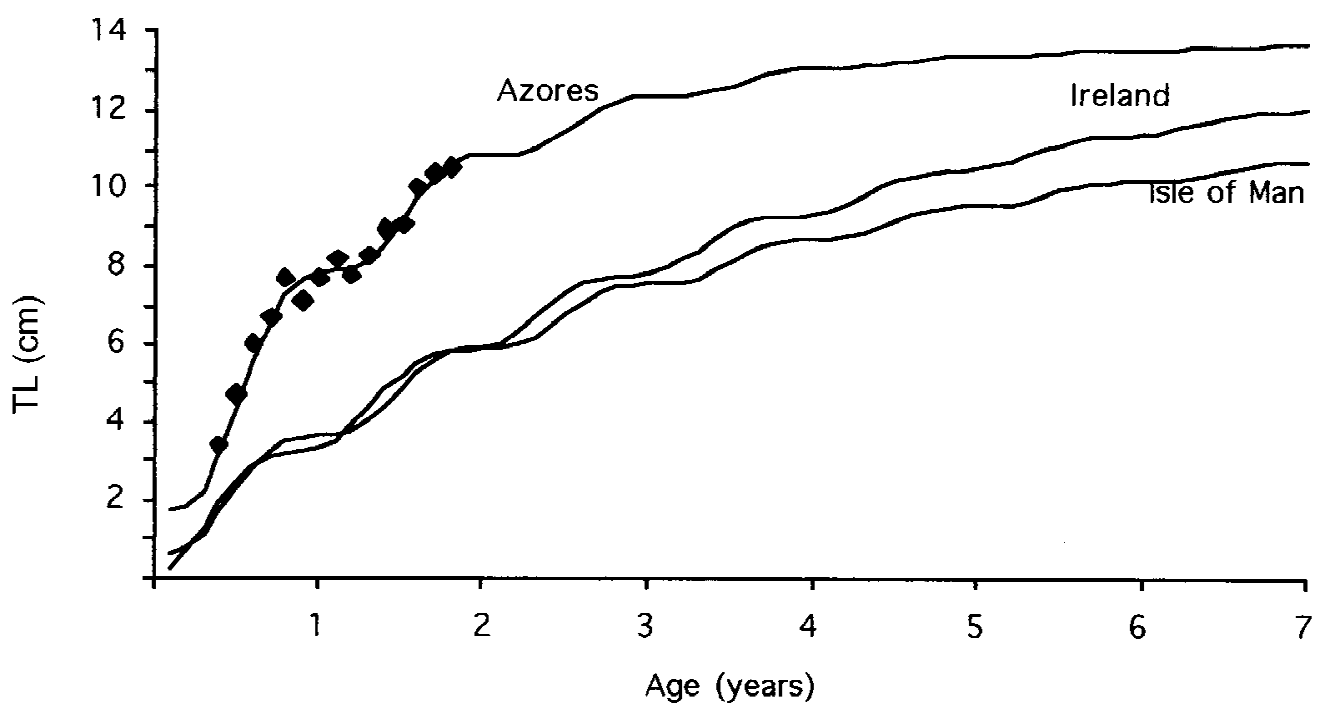

Figure 2. Growth curves for different populations of Gobius paganellus: Azores (present study), Ireland (Dunne, 1978) and Isle of Man (Miller, 1961). Points show age-length values obtained by modal analysis. See text for curve parameters.

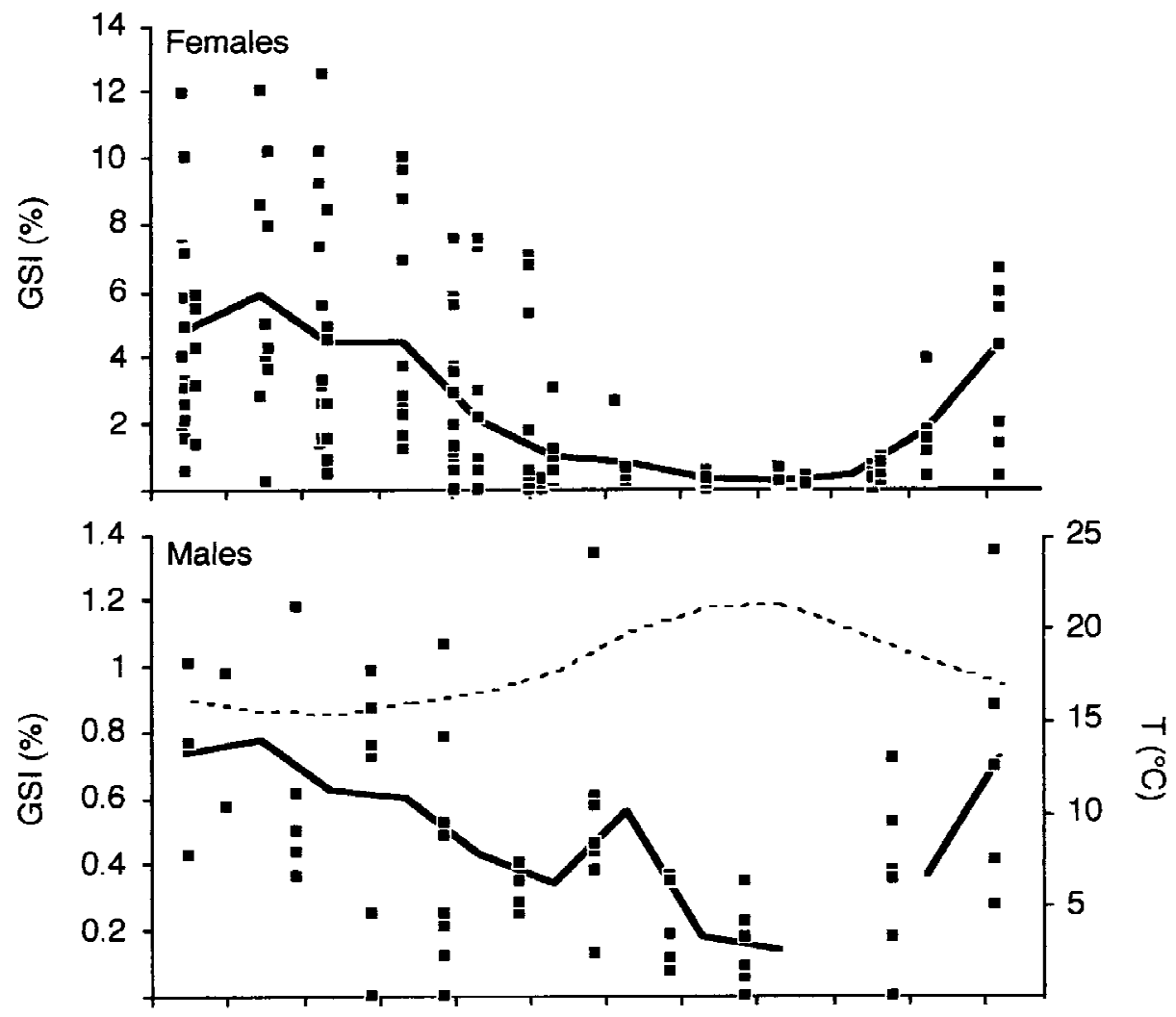

Jan Feb Mar Apr May Jun Jul Aug Sep Oct Nov Dec

Figure 3. Monthly values of the gonadosomatic index for each sex of Gobius paganellus. The solid line connects the monthly averages. Note different scales on the GSI axes of each graph. 


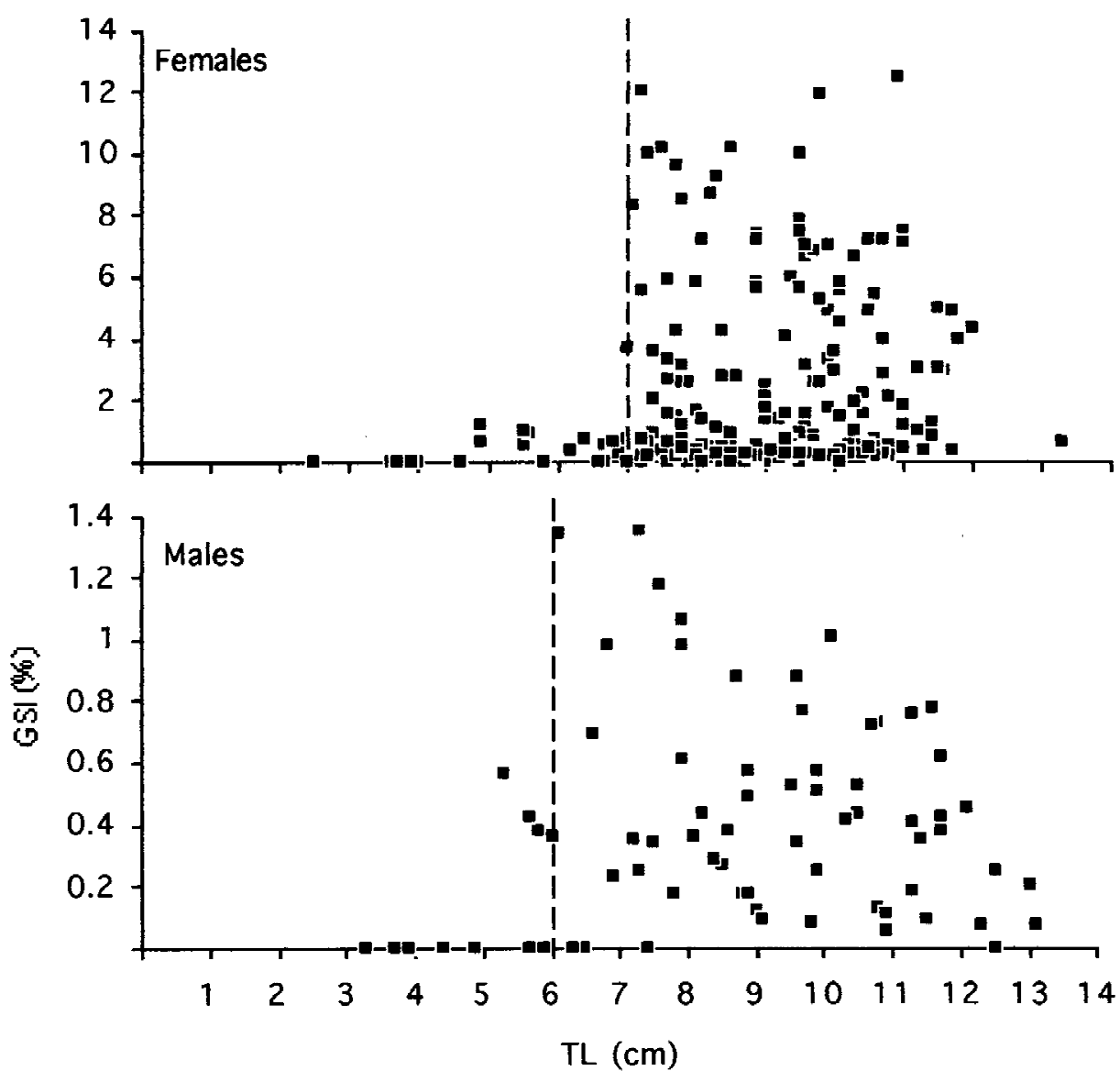

Figure 4. Length-GSI relationship for both sexes of the studied population of Gobius paganellus. Broken line mark presumptive size at first sexual maturation. Note different scales on the GSI axes of each graph.

\section{Food}

Table 3 shows the percentage occurrence of different food items in rock goby stomachs. Small benthic invertebrates accounted for the bulk of diet. Dominant items were isopods and amphipods, although gastropods, polychaetes and crabs were observed frequently.

\section{Discussion}

Separate growth rates for each sex could not be assessed by the methods used in the present study, but the higher proportion of males in the largest length classes suggests that males grow faster than females. For the closely related G. niger from the Adriatic Sea, Fabi \& Giannetti (1985) also found a statistically significant dominance of males in the largest size classes; using otolith data, they showed that males grew faster than females. Miller (1961) and Dunne (1978) found no sexual differences in growth rate for G. paganellus.
The former author, however, noted the disappearance of the larger members of each age group, suggesting that selective mortality or migration to the subtidal could account for this. This disappearance could mask the effects of differences in growth rate between sexes.

The main difference between the growth curve deduced in this study from those of more northern locations (Miller, 1961; Dunne, 1978) is the higher value of $K$. This implies a faster growth rate for the Azores population. Arruda et al. (1993) reported agesize values intermediate between these two extremes for a population of $G$. paganellus from the Ria de Aveiro, near the centre of the west coast of mainland Portugal. In this latter work, the average length of $0+$ and $1+$ specimens was given as 6.2 and $7.3 \mathrm{~cm}$, respectively. These compare with sizes at the end of the first and second years of 3.3-3.7 and 5.9 for the British populations, and 7.9 and 10.9 for the Azores. There is an inverse correlation between growth rate and latitude, suggesting that temperature might be the 
Table 3. Stomach contents (percentage occurrence) of different populations of Gobius paganellus. Items occurring in more than half the stomachs analysed are shown in bold

\begin{tabular}{|c|c|c|c|c|c|c|}
\hline & & & $\begin{array}{l}\text { Present } \\
\text { study }\end{array}$ & $\begin{array}{l}\text { Gibson } \\
\text { (1972) }\end{array}$ & $\begin{array}{l}\text { Dunne } \\
\text { (1978) }\end{array}$ & $\begin{array}{l}\text { Costa } \\
(1988)\end{array}$ \\
\hline Algae & & & 3 & 16 & 37 & \\
\hline Foraminifera & & & & 1 & & \\
\hline Cnidaria & Hydrozoa & & & 1 & & \\
\hline Annelida & Polychaeta & & 11 & 7 & 30 & 71 \\
\hline Mollusca & Bivalvia & & 8 & & & \\
\hline Mollusca & Gastropoda & & 28 & 15 & 31 & \\
\hline \multirow[t]{17}{*}{ Arthropoda } & Chelicerata & Pycnogonida & & 8 & & \\
\hline & & Acarina & & 9 & & \\
\hline & Crustacea & Ostracoda & & 38 & 27 & \\
\hline & & Copepoda & 3 & 82 & 34 & \\
\hline & & Cirripedia & & 1 & & \\
\hline & & Cumacea & & 5 & & \\
\hline & & Euphausiacea & 3 & & & \\
\hline & & Decapoda & & & 15 & \\
\hline & & Decapoda, & 3 & & & \\
\hline & & Dendrobranchia & & & & \\
\hline & & Decapoda & 14 & 32 & & 19 \\
\hline & & Brachyura & & & & \\
\hline & & Mysidacea & & & & 14 \\
\hline & & Isopoda & 69 & 25 & & 24 \\
\hline & & Amphipoda & 100 & 69 & 67 & 33 \\
\hline & Insecta & Coleoptera & & 1 & & \\
\hline & & Diptera & & 8 & 42 & 1 \\
\hline \multirow[t]{2}{*}{ Echinodermata } & Ophiuroidea & & 11 & 11 & & 1 \\
\hline & & $N=$ & 36 & 170 & 329 & 21 \\
\hline
\end{tabular}

main factor involved. This was proposed originally by Dunne (1978) to explain differences between Carna and the Isle of Man populations. It must be pointed out, however, that other factors may be involved. In particular, the sublittoral habitat of the present population may be more benign in providing opportunities for feeding, unrestricted by tidal cycles, compared to the tide-pool habitat studied by the other authors.

Most individuals of the Azores population probably reproduce in their first year. This contrasts with the observations of Miller (1961) and Dunne (1978), who report a size at first maturation which corresponds to an age of 2-3 years. The eggs of $G$. paganellus, like those of most gobiids (Ruple, 1984), are demersal, with adhesive filaments. They are placed by the female under rocks or empty bivalve shells where they are guarded by the male until hatching (Miller, 1961). The larvae remain close to the bottom until metamorphoses (Russel, 1930), after which they assume the crypto- benthic behaviour of the adults. In the Plymouth area, the time span from spawning to absorption of the vitelline sac by the larvae is 30 days (Lebour, 1919). There is very little information regarding the following phases of larval development and none about the effect of temperature on development. In the Isle of Man, spawning takes place from mid-April to mid-June. Post-metamorphic juveniles (9.5-10.5 mm in length) are in rock pools by early August (Miller, 1961), almost 4 months after the beginning of the reproductive season. In the present study, the first recruits (TL between 2.8 and $4 \mathrm{~cm}$ ) were captured in May, in both years. Even assuming that spawning starts in January, these data are consistent with a faster larval development in the Azores. This accelerated life history of Azorean individuals may mean a shorter life span. The oldest fishes observed by Dunne (1978) belonged to the 7+ age group, but Miller (1961) reported specimens older than 10 years. No direct age determination 
was attempted in the present study but, if the longevity estimation measure proposed by Taylor (1962, $\mathrm{A}_{0.95}$, the time an individual takes to reach $95 \%$ of $L_{\infty}$ ) is used, the Azores population scores only 3.9, considerably lower than that of the Isle of Man (9.3) or Carna (11.1).

In the Azores, the diet of G. paganellus is based on small benthic invertebrates, generally similar to that of other populations. Crustaceans were the main stomach items in Ireland (Dunne, 1978) and in northern France (Gibson, 1972). Costa (1988), on the other hand, stated that the most frequent item in the population from the Tagus Estuary was polychaetes. This may be due to the peculiarities of this estuarine habitat, since the remaining areas were fully marine. Algal fragments have a frequency in the stomach contents of between 16\% (Costa, 1988) and 37\% (Dunne, 1978). This latter author suggested that algal material is ingested accidentally, together with the animal constituents of the diet. This view is substantiated by the present study, since algal fragments were found only in one of the 36 stomach contents analysed.

\section{References}

Arruda, L., J. M. N. Azevedo \& A. I. Neto, 1993. Abundance, age-structure and growth, and reproduction of gobies (Pisces; Gobiidae) in the Ria de Aveiro Lagoon (Portugal). Estuar. coast. Shelf Sci. 37: 509-523.

Azevedo, J. M. N., 2000. Now you see me, now you don't: a case study of the effect of the sampling method on the perceived structure ichthyological communities. Arquipélago, Life Mar. Sci. Supp. 2(a): 133-143.
Costa, M., 1988. Écologie alimentaire des poissons de l'estuarie du Tage. Cybium 12 (4): 301-320.

Dunne, J., 1978. The biology of the rock goby, Gobius paganellus L., at Carna. Proc. r. Irish Acad. 78B (12): 179-191.

Fabi, G. \& G. Giannetti, 1985. Growth parameters of the black goby (Gobius niger L.) in the Adriatic Sea, based on otholiths reading. Rapp. Comm. int. Mer Médit. 29(8): 87-90.

Gayanillo, F. C. Jr., P. Sparre \& D. Pauly, 1994. The FAO-ICLARM stock assessment tools (FiSAT) user's guide. FAO, Rome: 186 pp.

Gibson, R. N., 1972. The vertical distribution and feeding relationships of intertidal fish on the Atlantic coast of France. J. anim. Ecol. 41: 189-207.

Lebour, M. V., 1919. The young of the Gobiidae from the neighbourhood of Plymouth. J. mar. biol. Ass. U.K. 12: 48-80.

Miller, P., 1984. The gobiid fishes of temperate Macaronesia (Eastern Atlantic). J. Zool., Lond. 204 (3): 363-412.

Miller, P., 1986. Gobiidae. In Whitehead, P. J. P., M.-L. Beauchot, J.-C. Hureau, J. Nielsen \& E. Tortonese (eds), Fishes of the Northeastern Atlantic and the Mediterranean. UNESCO, Paris: 1019-1085.

Miller, P. J., 1961. Age, growth, and reproduction of the rock goby, Gobius paganellus L., in the Isle of Man. J. mar. biol. Ass. U.K. 41: 737-769.

Patzner, R., R. Santos, P. Ré \& R. Nash, 1992. Littoral fishes of the Azores: an annotated checklist of fishes observed during the 'Expedition Azores 1989'. Arquipélago, Life Earth Sci. 10: 101111.

Ruple, D., 1984. Gobioidei: development. In Moser, H. G. (ed.), Ontogeny and Systematics of Fishes. American Society of Ichthyologists and Herpetologists, Special Volume nr. 1: 582-587.

Russel, F., 1930. The vertical distribution of marine macroplankton. IX. The distribution of the pelagic young of teleostean fishes in the Plymouth area. J. mar. biol. ass. U. K. 15: 829-850.

Sparre, P. \& S. Venema, 1992. Introduction to tropical fish stock assessment. Part 1. Manual. FAO Fisheries Technical Paper 306/1. FAO, Rome: 376 pp.

Taylor, C., 1962. Growth equations with metabolic parameters. J. Con. perm. int. Explor. Mer. 27: 270-286. 